\title{
Distribution and conservation status of Congo Peafowl Afropavo congensis in eastern Zaire
}

\author{
JOHN A. HART and AGENOGA UPOKI
}

\begin{abstract}
Summary
Between 1993 and 1995 the occurrence and status of Congo Peafowl Afropavo congensis were assessed at 89 sites in eastern Zaire based on interviews with local hunters (114 locations) and forest surveys ( 24 locations). The survey region covered approximately $125,000 \mathrm{~km}^{2}$ and was bounded by the Lomami River $\left(24^{\circ} 30^{\prime}\right)$ to the west, the Albertine Rift Highlands $\left(29^{\circ}\right)$ to the east, the Aruwimi River $\left(2^{\circ} \mathrm{N}\right)$ to the north and the Kahuzi Biega Park $\left(3^{\circ} \mathrm{S}\right)$ to the south. Congo Peafowl have been extirpated or were only doubtfully present at 16 of 65 sites where survey coverage was adequate and where the species was reported to have occurred in the past. Occurrence of the species was confirmed or probable at the remaining 49 sites. Congo Peafowl were reported as locally common ( $>$ five reported encounters since 1990) at only 12 sites. We observed or heard peafowl at five sites. A single nest was found which contained two eggs. Observations on group size and habitat associations were also made. Congo Peafowl were considered to be seriously threatened at 19 of the 65 sites. Captures in snares set for small mammals and antelope are a major threat to Congo Peafowl throughout most of the survey region. Mining, shifting cultivation and logging leading to habitat loss were significant threats in several locations. Congo Peafowl appear to have disappeared from several sites where human activity was frequent, but habitat loss was not extensive. The mass movements of Rwandan refugees into eastern Zaire, which began in 1994, pose a threat to Congo Peafowl in a number of areas. Conservation of the Congo Peafowl in eastern Zaire is best assured in the Maiko National Park where the species appears to be locally common. Further surveys within the Congo Peafowl's range in central Zaire, and study of the behaviour and ecological needs of the species are recommended.
\end{abstract}

\section{Introduction}

Despite its remarkable discovery and ornithological importance as the only African pheasant, the Congo Peafowl Afropavo congensis has remained a little-known and mysterious bird. Verheyen (1962), summarizing what was learned of the bird's distribution in the 25 years following its discovery in 1936, reported occurrences in fewer than 50 locations scattered over an area of about $400,000 \mathrm{~km}^{2}$ in central and eastern Zaire. Additional locations for the Congo Peafowl were added in the decades from Zaire's independence to the present, including several new locations that extended the known global range of the species (Verschuren 1978, Van Bocxstaele 1985, Thompson 1996, Dupain et al. in press, J. R. Wilson and M. C. Catsis unpublished 1990). Nevertheless, locations 
where the species has been recorded remain remarkably infrequent across continuous rainforest habitat within the global range.

This lack of knowledge is of concern as a number of areas where the bird was originally reported have been opened to logging, mining and settlement. With human population growth exceeding $2.5 \%$ annually in Zaire, including the mass arrival of Rwandan refugees into the region in 1994, the pressure from hunting and clearing on the remaining forest areas is likely to be large. Is the Congo Peafowl still holding its own, or is it quietly slipping toward extinction?

Between 1993 and 1995 we conducted a survey to investigate the distribution and current status of the Congo Peafowl in the eastern portion of its range. Objectives of this study were: (1) to visit previously known locations for Congo Peafowl to establish its current occurrence and status; (2) to visit as many new locations as possible where the Congo Peafowl has not previously been reported, but where it could be expected based on its known range; (3) to acquire information on the biology and habitat requirements of the species; and (4) to establish conservation status and provide recommendations for in situ conservation of the species.

\section{Survey region}

Fieldwork for this survey covered an area of $125,000 \mathrm{~km}^{2}$ (Fig. 1) and was conducted over a 30-month period from March 1993 to August 1995. The survey region, covers over one third of the Congo Peafowl's known range and includes some of the earliest documented locations for the species' occurrence.

Elevations of the survey region range from about $450 \mathrm{~m}$ in the west along the Zaire River and in the valleys of the lower Lomami, Aruwimi and Lindi rivers, to about $1400 \mathrm{~m}$ in the montane transition zone bordering the Albertine Rift highlands in the east. Most of the survey region consists of gently undulating uplands between $500 \mathrm{~m}$ and $1000 \mathrm{~m}$ elevation. Localized massifs of hills rising from 100 to $500 \mathrm{~m}$ above the surrounding plane occur in the headwaters and along the divides of many of the major drainage systems.

The survey region's forests have been classified as mixed, moist semi-evergreen rainforest (White 1983). Primary forests over much of this area are dominated by Caesalpiniaceous species with monodominant stands of Gilbertiodendron dewevrei covering large areas in the watersheds of the Lindi, Tshopo and Ituri/Aruwimi rivers. Floristic surveys have been conducted at only a few sites, including Yangambi, west of Kisangani on the Zaire River (Germain and Evrard 1956), in the Uelle basin, north of Kisangani (Gérard 1960), and in the central Ituri Forest (Hart et al. 1996). Forests on the region's massifs remain poorly known. Chapin (1932) provides an account of the forests of the eastern part of the survey region specifically in relation to its avifauna.

Small-scale shifting cultivation occurs widely throughout the survey area but this has not resulted in major forest loss in most areas. Several large blocks of nearly uninhabited forests remain in the Tshopo, Lindi, Maiko and Ituri basins. Deforestation is most evident in the east, especially along the transition to the Albertine highlands where intensive shifting cultivation and coffee plantations have removed large areas of forest in some areas. Large-scale deforestation has 


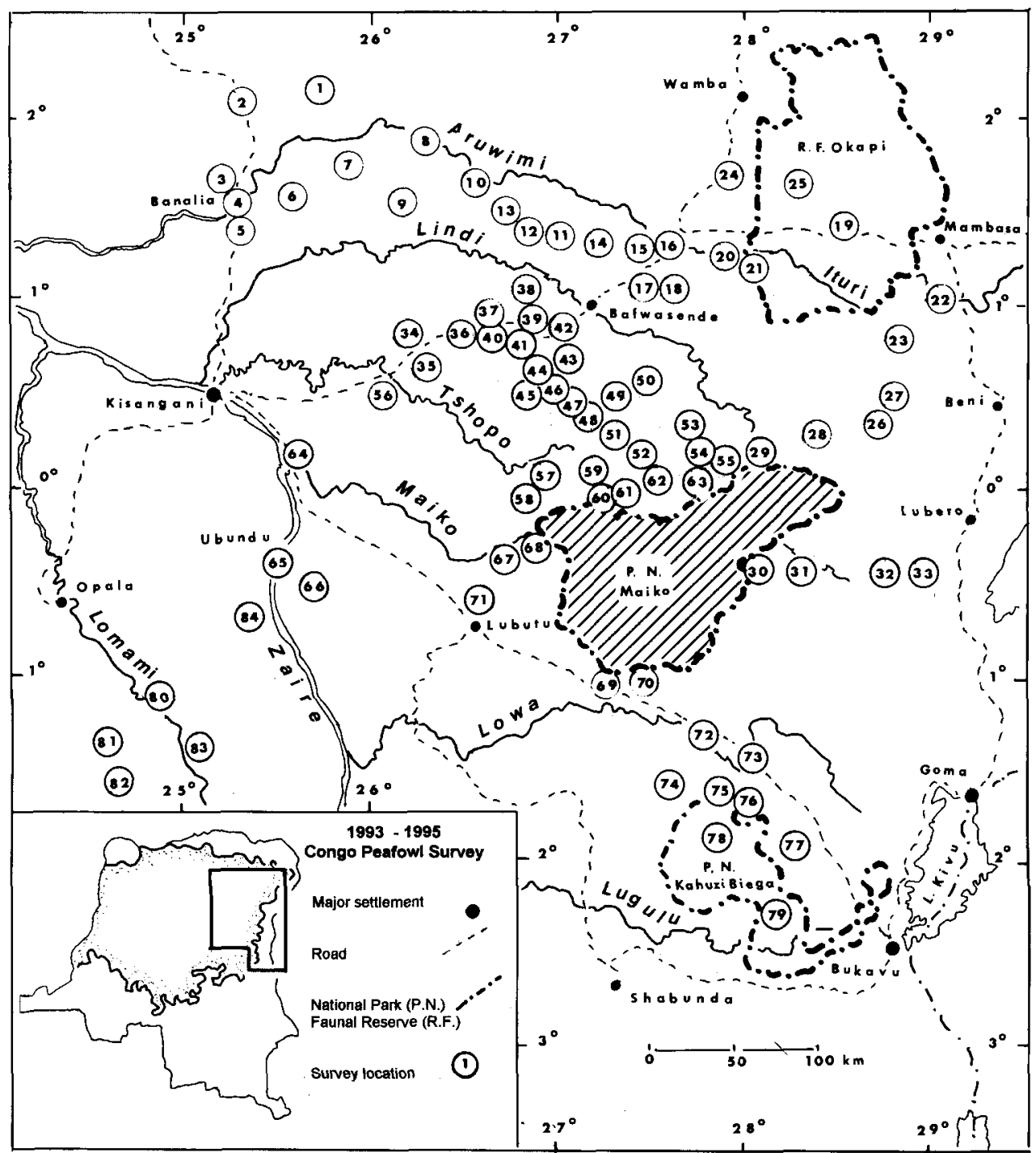

Figure 1. The 1993-1995 Congo Peafowl survey area in eastern Zaire. Numbered circles locate survey sites listed in Appendix 1. Survey sites in Maiko National Park are detailed in Table 3 and shown in Figure 3.

also occurred, locally along the Zaire River and the lower stretches of its major tributaries the Aruwimi, and Lindi.

Mechanised logging has been restricted to portions of the Lindi, Tshopo and Aruwimi basins in the western half of the survey area. Although only a small percentage of the trees are removed, and forest cover remains over most of this area, the logging operations have created access routes into the forest thus allowing penetration of previously remote areas by hunters and prospectors. 
Gold has been mined widely over eastern Zaire, including the study region, for over 80 years. Scattered pockets of diamonds have been exploited in portions of the Lindi, Tshopo and Lower Aruwimi basins over the last 10 years. Although none of these mining operations is mechanised, larger strikes can draw several hundred miners and traders. Most mining camps, even smaller ones, have associated hunters who provision prospectors and traders with wild meat.

Three major protected forest areas, the Kahuzi-Biega National Park, the Maiko National Park and the Okapi Wildlife Reserve, covering together almost $29,000 \mathrm{~km}^{2}$, are included within the survey area. Hunters and prospectors are active in many areas within these parks and reserves, although significant wildlife populations remain (Hart and Hall 1996). Since completion of fieldwork for this survey, eastern Zaire has been overcome by political upheaval with establishment of refugee camps in a number of areas including the vicinities of the Maiko and Kahuzi-Biega National Parks (Hart and Hart 1997).

\section{Methods}

Preliminary surveys established that we would not be able to census Congo Peafowl populations directly by visual or auditory counts. Indirect evidence of the species, including roosts and dusting sites were also not readily visible or were easily confused with signs of guineafowl and francolins. We assessed occurrence of Congo Peafowl by interviews with local hunters. Forest visits were made at selected sites where interviews indicated that the birds were likely to be encountered. In this report, the term "survey site" will refer to the forest areas identified by interview respondents and not necessarily to the location where the interview was conducted.

\section{Interviews}

We divided the survey region into sectors that were defined by geographical features such as river basins or protected area boundaries, or were determined by logistical constraints such as accessibility. Survey expeditions into each of these areas lasted from 2 to 4 weeks. Throughout the survey area, whenever possible, we requested the authorization of traditional and state authorities in order to facilitate contact with local hunters who might otherwise be reluctant to provide us with information. Interviews were conducted in Swahili or Lingala by both authors and by Alexis Bwanandeke, a ranger from the Maiko National Park trained by the project, and using a prepared form to guide the interview. During each interview, informants were asked to describe both sexes of the Congo Peafowl in order to establish their familiarity with the species (vernacular names "Itundu", "Litondo" or "Nkowe"). For each reported direct encounter with Congo Peafowl, the date, and location (as precisely as possible), sex of bird, if known, and any details of the observation were requested. Assessment of hunting, mining and deforestation levels and overall threat to Congo Peafowl were made at each survey site based on interview information and site visits. 


\section{Forest visits}

Where interviews suggested that Congo Peafowl occurred within 3-4 hours march of our point of access, we accompanied hunters to sites where the bird had been recently seen, a nest had been found, or where Congo Peafowl had been recently caught in snares. At each site, forest type and topography were noted and canopy and understorey were described. At sites where Congo Peafowl were caught in snares, feathers were collected if available. Position, behaviour and the number and sexes of birds were recorded for each sighting. Location and time of day were noted for each call we heard. Congo Peafowl are reported to respond to hunters' imitations of antelope bleats (Verheyen 1965); however, we were unable to elicit this response by birds when we attempted this ourselves.

\section{Transect surveys in the Maiko National Park}

Observations of Congo Peafowl, supplemented by information provided by local guides and porters were recorded during a 3-year (1989-1992) inventory of the Maiko National Park (Hart and Sikubwabo 1994). The date, location and sex, if determined, were noted for each encounter of Congo Peafowl along $947 \mathrm{~km}$ of transects and path surveys within the park and adjacent hinterland. Locations of Congo Peafowl occurrence in the Maiko Park are mapped in $10 \times 10 \mathrm{~km}$ grid divisions of the park utilized in the original survey.

\section{Results}

\section{Interviews}

Interviews were conducted at 114 towns, villages, hunting and mining camps during the 1993-1995 survey. These interviews provided information regarding the occurrence of Congo Peafowl at 89 survey sites (Figure 1), with sites in the Maiko National Park shown in Figure 3.

Complete interview coverage, defined as having at least three informants provide complete responses to questionnaires, was achieved at 52 interview locations. Few people refused to be interviewed. Locations where we conducted fewer than three interviews were generally in small settlements or camps where there were not enough hunters present to respond to our queries. Appendix 1 provides a complete listing of interview locations, survey sites, occurrence of Congo Peafowl, and a profile of site conditions.

\section{Occurrence of Congo Peafowl}

The presence or absence of Congo Peafowl at survey sites was determined with three levels of certainty (Table 1). A high degree of certainty was achieved at 42 survey sites. A lower probability of occurrence was associated with an additional 30 sites. At 17 sites information to evaluate occurrence was insufficient. Congo Peafowl have never been observed, and probably have never occurred, at seven survey sites. Congo Peafowl have probably been extirpated or were only 


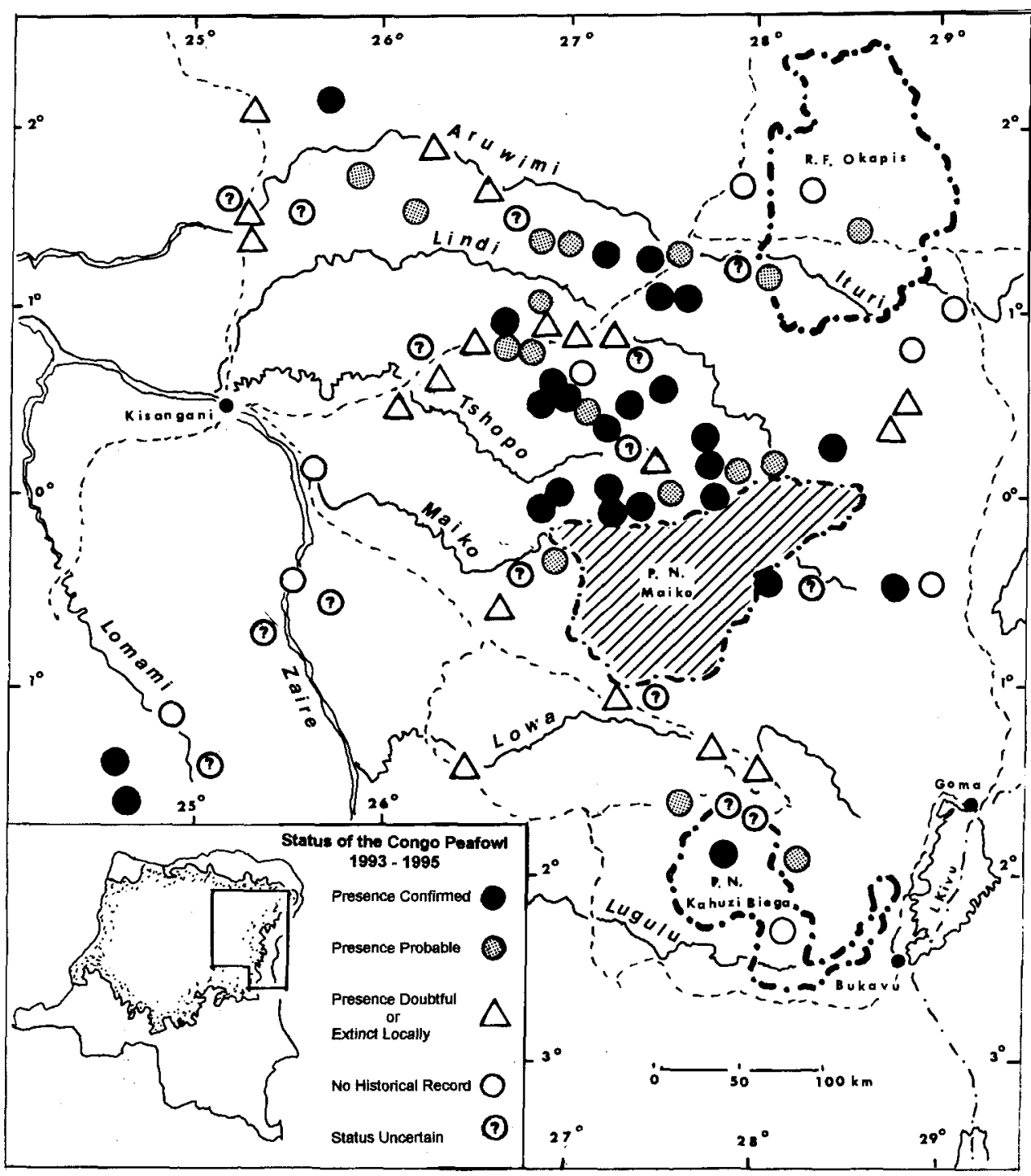

Figure 2. Occurrence of Congo Peafowl in eastern Zaire, 1993-1995. For occurrences in the Maiko National Park see Table 3 and Figure 3.

doubtfully present at 16 of 65 sites where survey evaluation was adequate and where they have been reported to have occurred at some time in the past (Table 2).

Figure 2 maps the occurrence of Congo Peafowl at 84 survey sites outside the Maiko Park. Table 3 and Figure 3 provide information on the occurrence of Congo Peafowl within the Maiko Park and its immediate vicinity, including observations made during the original 1989-1992 exploration of the park.

We classified the Congo Peafowl as locally common at 12 sites where the species was either observed or reported with a high degree of certainty. Congo 


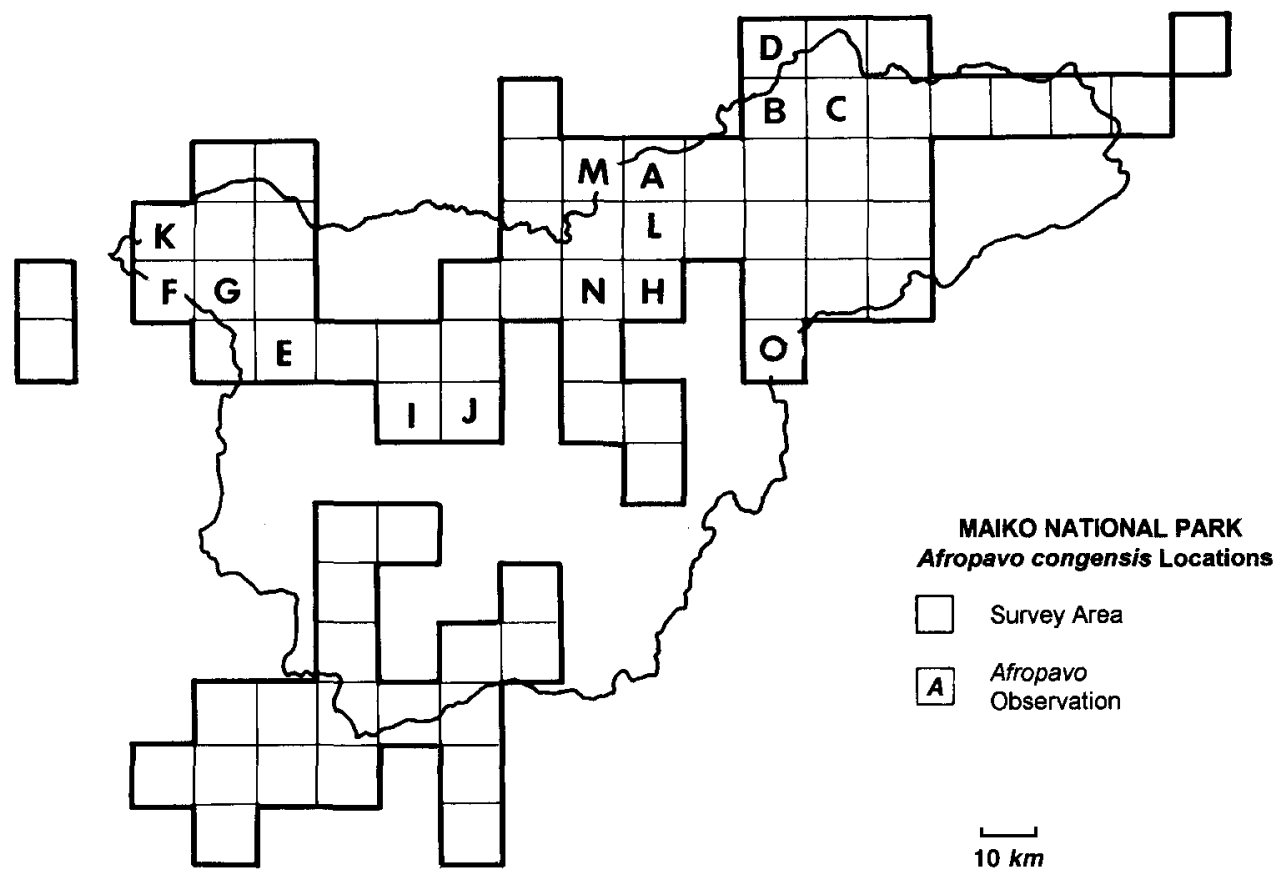

Figure 3. Occurrence of Congo Peafowl in the Maiko National Park. Grid squares locate 1989-1992 survey area. Letters refer to observations described in Table 3.

Table 1. Criteria for establishing occurrence of Congo Peafowl at survey sites based on interviews

\begin{tabular}{lll}
\hline $\begin{array}{l}\text { Degree of } \\
\text { certainty }\end{array}$ & Occurrence & Criteria \\
\hline High & Absent, never observed & $\geq 3$ informants; no historical knowledge of Congo \\
& Peafowl & \\
& Absent, locally extirpated & $\geq 3$ informants; historical occurrence of Congo \\
& Peafowl; no reports after 1975 \\
& $\geq 3$ informants; <5 Congo Peafowl reports after 1990; \\
& few informants with direct experience \\
& $\geq 3$ informants; $\geq 10$ reports Congo Peafowl after \\
& Uncommon & $\geq 5$ reports after 1990; frequent direct \\
& Locally common & experience; information on food habits and behaviour \\
& & provided \\
& & $<3$ informants; historical occurrence of Congo \\
& Peafowl; no reports after 1985; local conditions \\
& indicate current occurrence of Congo Peafowl unlikely \\
& Doubtful & $<3$ informants; Congo Peafowl reports after 1985 \\
& & Inadequate interview response \\
\hline
\end{tabular}

Peafowl were classified as uncommon at $\mathbf{1 8}$ sites. This category combined sites where populations are likely to have been limited for a variety of reasons, including availability of suitable habitat and heavy hunting pressure, as well as sites at the edge of the species's range where the bird may have never been common. It is not known whether these uncommon occurrences represent small, 
Table 2. Occurrence of Congo Peafowl at $1993-1995$ survey sites in eastern Zaire

\begin{tabular}{lc}
\hline Occurrence & Sites \\
\hline Absent, never observed & 7 \\
Absent, locally extirpated & 5 \\
Uncommon & 18 \\
Locally common & 12 \\
Doubtful & 11 \\
Probable & 19 \\
Evaluation not possible & 17 \\
& \\
Total & 89
\end{tabular}

${ }^{\text {a }}$ Includes 84 sites (Figure 2) and 5 sites in Maiko National Park (Figure 3).

Table 3. Congo Peafowl occurrence in the Maiko National Park

\begin{tabular}{|c|c|c|c|c|c|}
\hline Location & Mapa $^{a}$ & Year $^{b}$ & Observation & Forest type & Interview report \\
\hline Ogombo Massif & A & 1989,1995 & $\begin{array}{l}3 \text { heard; } \\
2 \text { males sèen }\end{array}$ & Mixed hill forest & $\begin{array}{l}\text { Widespread and frequent } \\
\text { in hills }\end{array}$ \\
\hline $\begin{array}{l}\text { Obilota, Etabili } \\
\text { Valleys }\end{array}$ & $B, C$ & 1990 & & & $\begin{array}{l}\text { Reported in lowland and } \\
\text { hills }\end{array}$ \\
\hline R. Amagbada & D & 1990 & 2 females seen & Lowland forest & \\
\hline R. Ongeno & E & 1991 & & & Occurs in hills \\
\hline R. Amefufuma & F & 1991 & & & Occurs in hills \\
\hline R. Demani & G & 1991 & 2 heard & Mixed hill forest & Mixed hill forest \\
\hline $\begin{array}{l}\text { Source R. } \\
\text { Akimali }\end{array}$ & $\mathrm{H}$ & 1992 & & & Frequent in hills \\
\hline R. Engule & I & 1992 & 3 heard & $\begin{array}{c}\text { Mixed lowland } \\
\text { forest }\end{array}$ & \\
\hline Silisa & $\mathrm{J}$ & 1992 & I heard & $\begin{array}{l}\text { Old secondary } \\
\text { forest }\end{array}$ & $\begin{array}{l}\text { Occurs in hills, secondary } \\
\text { forest }\end{array}$ \\
\hline Amedue & K & 1992 & & & Occurs in hills \\
\hline Mt. Mogogoligo & $\mathrm{L}$ & 1995 & & & 6 seen in hills \\
\hline Loya Patrol Post & $M$ & 1995 & 1 heard & Lowland forest & \\
\hline W. Angumu & $\mathrm{N}$ & 1995 & 3 heard & & $\begin{array}{l}\text { Kaseny, Muwa Abankale } \\
\text { valleys }\end{array}$ \\
\hline $\begin{array}{l}\text { Mandaye Patrol } \\
\text { Post }\end{array}$ & $\mathrm{O}$ & 1995 & $\begin{array}{l}\text { Male and } \\
\text { female seen }\end{array}$ & Lowland forest & Lowland forest \\
\hline
\end{tabular}

a Letters refer to locations on Map of Maiko National Park (Figure 3).

b 1989 -1992 observations by Hart and Sikubwabo (1994). 1995 observations current survey.

Table 4. Forest site visits 1993-1995: Congo Peafowl observations

\begin{tabular}{cccccccc}
\hline Seen & Heard & Nest & $\begin{array}{c}\text { Dusting } \\
\text { site }\end{array}$ & $\begin{array}{c}\text { Snare } \\
\text { capture }\end{array}$ & $\begin{array}{c}\text { Observation } \\
\text { by guide }\end{array}$ & $\begin{array}{c}\text { No } \\
\text { observation }\end{array}$ & $\begin{array}{c}\text { Total } \\
\text { survey sites }\end{array}$ \\
\hline 3 & 1 & 1 & 2 & 4 & 2 & 16 & 24 \\
\hline
\end{tabular}

poorly known resident populations, or sporadic dispersal events by Congo Peafowl into areas that are not permanently occupied.

\section{Forest surveys: observations of Congo Peafowl}

Sightings of Congo Peafowl by the field teams during the original Maiko Park study (Table 3) and at 24 sites during the 1993-1995 survey (Table 4) included 
four observations of paired birds and four single birds (two males and two females). All birds were initially observed on the ground, and in most cases retreated from observers by running along the ground. One pair was observed travelling with a group of Latham's Francolin Francolinus lathami. The Congo Peafowl appeared to be alone in the other observations. Birds were heard to call soon after dark between 19 hoo and 22 hoo and once at dawn.

A Congo Peafowl nest was shown to Alexis Bwanandeke by a local hunter in November 1994. The nest was located on the ground under a fallen tree trunk in relatively open, mature forest. There were two eggs in the nest when found. The next day, both male and female were seen near the nest. Alexis was unable to observe incubation directly.

Single birds and pairs comprised the majority of reported sightings provided by local hunters who were interviewed (Figure 4). Observations of larger groups
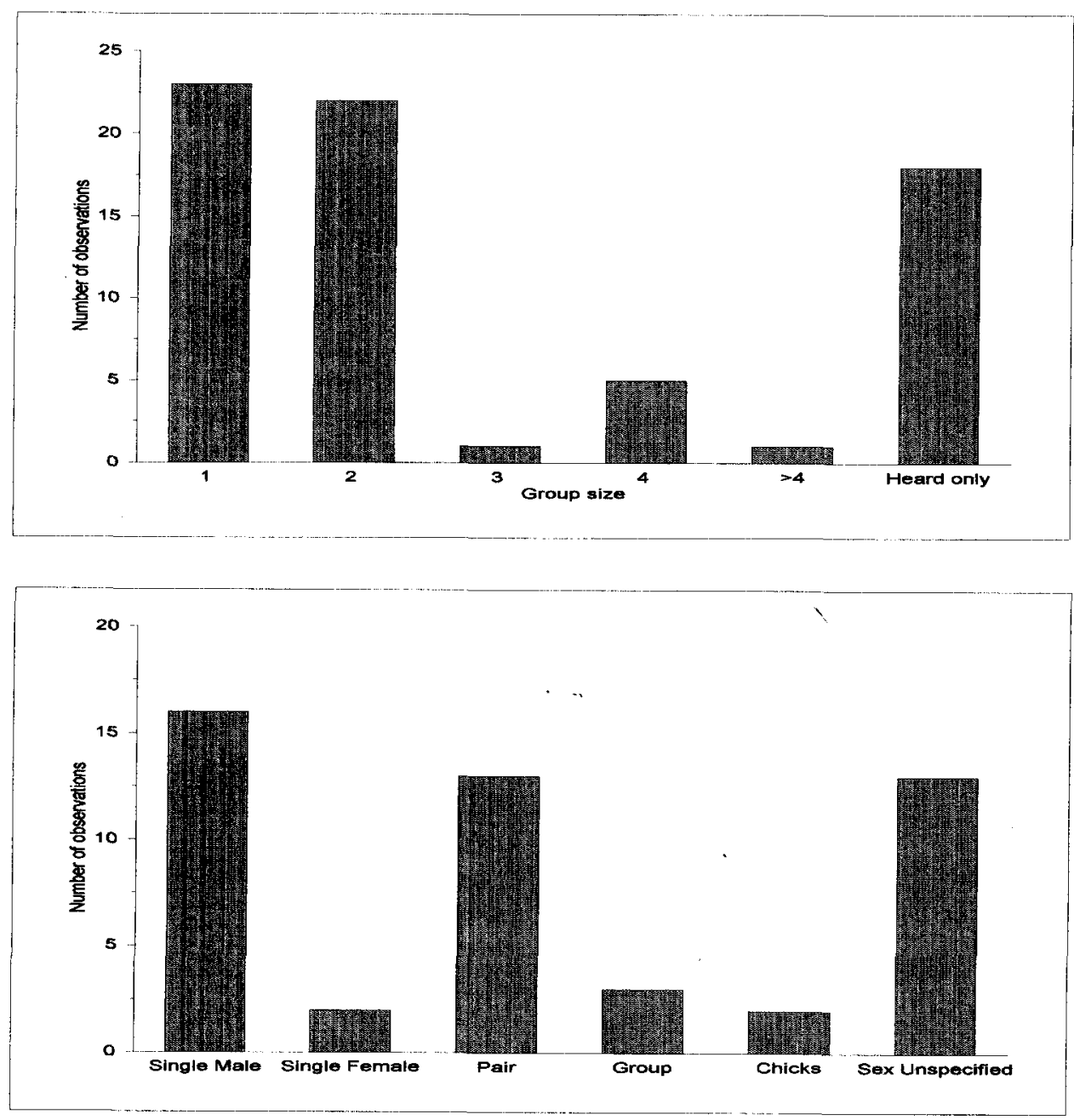

Figure 4. Number of observations and group size of Congo Peafowl made between 1990 and 1995 reported by interviewed informants. 
Table 5. Conservation status and site conditions: 1989-1995 Congo Peafowl survey

\begin{tabular}{|c|c|c|c|c|c|c|c|c|}
\hline \multirow{3}{*}{$\begin{array}{l}\text { Status of Congo } \\
\text { Peafowl }\end{array}$} & \multirow{3}{*}{$\begin{array}{l}\text { Survey } \\
\text { sites }^{\mathrm{a}}\end{array}$} & \multicolumn{7}{|c|}{ Percentage of sites } \\
\hline & & \multicolumn{2}{|c|}{ Hunting pressure } & \multicolumn{2}{|c|}{ Deforestation } & \multicolumn{3}{|c|}{ Artisinal ${ }^{a}$ mining } \\
\hline & & Low & High & Minimal & Extensive & None & Minimal & Extensive \\
\hline $\begin{array}{l}\text { Minimally } \\
\text { threatened }\end{array}$ & 40 & 95.0 & 5.0 & 100.0 & 0.0 & 17.5 & 60.0 & 22.5 \\
\hline $\begin{array}{l}\text { Seriously } \\
\text { threatened }\end{array}$ & 19 & 10.5 & 89.5 & 89.5 & 10.5 & $5 \cdot 3$ & 42.1 & 52.6 \\
\hline Probably extirpated & 16 & 12.5 & 87.5 & 25.0 & 75.0 & 12.5 & 31.2 & 56.3 \\
\hline Unknown & 17 & 23.5 & 75.5 & 88.2 & 11.8 & 23.5 & 53.0 & 23.5 \\
\hline Total sites & 92 & 50.0 & 50.0 & 82.6 & 17.4 & 15.2 & 50.0 & 34.8 \\
\hline
\end{tabular}

${ }^{a}$ Included are 82 sites in the 1993-1995 survey with known or possible historical occurrence of Congo Peafowl plus 10, 10 $\mathrm{km} \times 10 \mathrm{~km}$ sample blocks in the Maiko Park with occurrence of Congo Peafowl recorded in 1989-1992 that were not sampled in 1995.

were mostly reported as families (pairs with young). One informant reported having an adult male, accompanied by three chicks, fly at him when he encountered them in the forest. The largest group reported contained six birds. Reported sightings of single cocks far outnumbered single hens. We do not know whether this reflects actual sex ratios in the wild, higher visibility of males or possibly inaccurate reporting by informants.

Most of our observations of Congo Peafowl were made in primary forest. One bird was heard calling from degraded primary forest near a village and several informants reported seeing birds in old secondary forest. We have no reports of Congo Peafowl in swamp forest or seasonally inundated areas and none from younger regenerating agricultural clearings. Nearly half of our observations of Congo Peafowl were made in hilly areas, including drier ridges. Local hunters also frequently reported encounters with the Congo Peafowl from this same type of forest.

We made no direct observations of Congo Peafowl feeding. The crop of one dead bird examined contained small, unidentified seeds. Informants mentioned birds attracted to fruiting Musanga cecropioides and Margeritaria discoidea.

\section{Site conditions and threats to Congo Peafowl}

Table 5 summarizes the relationship between the conservation status of Congo Peafowl in relation to hunting pressure, deforestation and mining activities at survey sites, including the locations of Congo Peafowl occurrence recorded during the original Maiko Park exploration. Congo Peafowl were considered to be seriously threatened if informants reported declining frequency of contact with, or disappearance of, the bird from areas where they were previously known.

Hunting With the exception of remote areas in the Maiko National Park and the southwestern and central core areas of the Okapi Wildlife Reserve, subsistence hunting was recorded at all survey sites. Levels of hunting were considered low where human population was low and there was no hunting 
for commercial markets. Hunting pressure was defined as heavy where hunters provisioned a commercial meat trade, or at survey sites near larger settlements where many subsistence hunters operated. Low hunting pressure characterized $46(50 \%)$ of 92 sites surveyed within the Congo Peafowl's range in eastern Zaire. Heavy hunting pressure characterized nearly $88.6 \%$ of all survey sites where Congo Peafowl were considered seriously threatened, or probably extirpated.

Most hunters who acknowledged catching Congo Peafowl reported that they caught them incidentally in snares and traps set for other species (Figure 5). Wire or nylon cord snares set along game trails for duikers were the most frequently cited source of captured Congo Peafowl. Barrier snares consisting of a low drift fence with openings at which snares are set for small terrestrial mammals were a second major source of captured peafowl. Only two informants reported killing
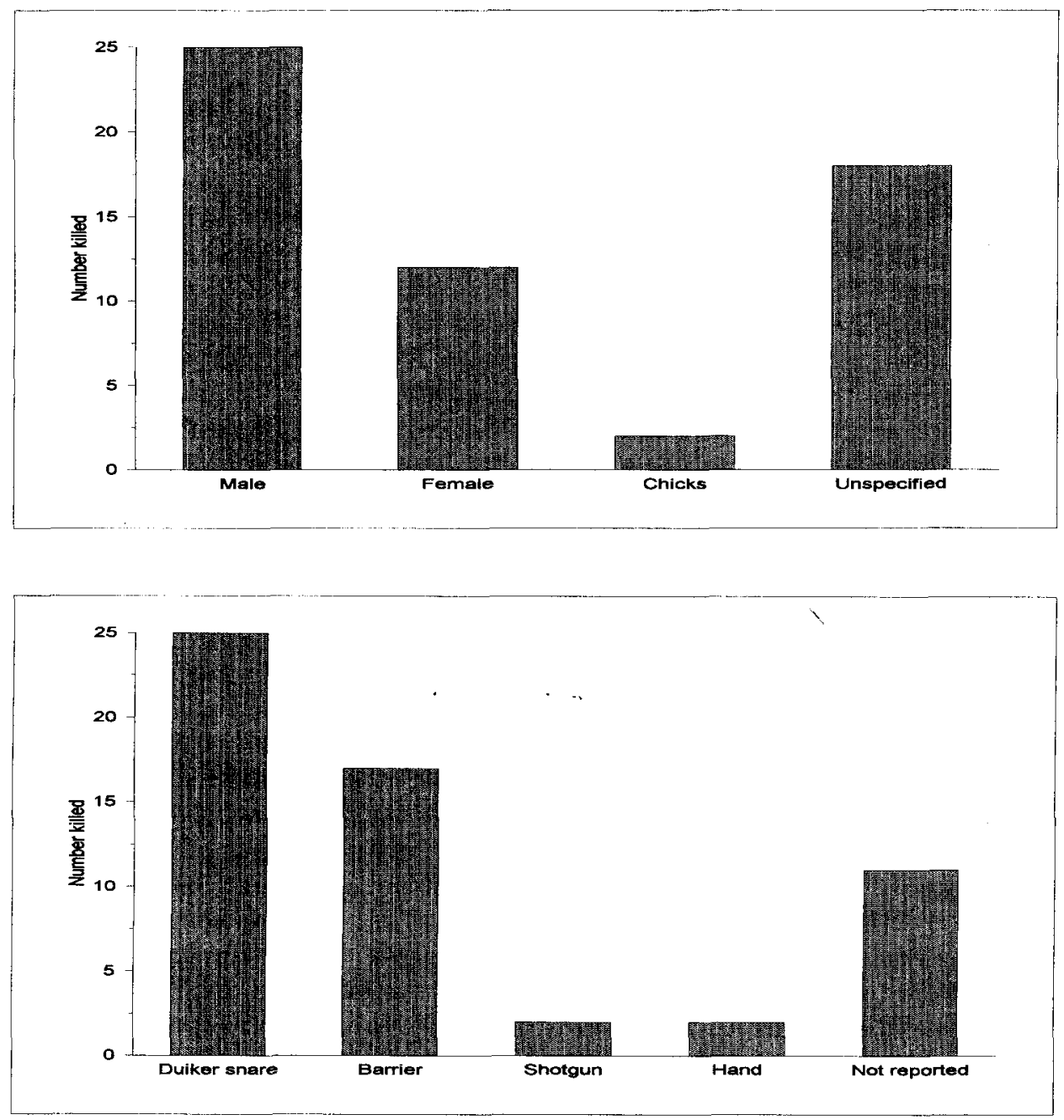

Figure 5. Captures and capture methods of Congo Peafowl made between 1985 and 1995 reported by interviewed informants. 
Congo Peafowl with shotguns between 1985 and 1995. In general hunters reported that Congo Peafowl are too small to be worth expending a shell. Males represented $67.6 \%$ of captured birds in reports where the bird's sex was given (Figure 5).

Deforestation Deforestation was defined as minimal at sites where human clearings and agriculture were currently absent, or where there were only small numbers of shifting cultivators and no other source of deforestation. Sites where deforestation was classified as extensive included larger settlements with major clearings, heavily exploited logging concessions and sites where population density was estimated at more than three persons per square kilometre.

Overall, deforestation levels were low throughout the survey area. Nearly $83 \%$ of survey sites were characterized as having minimal deforestation. Extensive deforestation characterized only two of 19 sites where Congo Peafowl were considered seriously threatened. Extensive deforestation on the other hand, characterized 12 of 16 sites where Congo Peafowl had been locally extirpated.

Mining Some level of artisanal mining was recorded at $85 \%$ of all survey sites in the region. Mining activity was classified as minimal at most sites (seasonal activity only with camps < 50 people), including $60 \%$ of sites where Congo Peafowl were considered minimally threatened. Ten of 19 sites where Congo Peafowl were classified as seriously threatened had extensive mining activity in the area, including multiple camps with year-round activity and camps with more than 50 people. Similar frequencies of larger scale mining were recorded at sites where Congo Peafowl were reported as extirpated.

\section{Discussion}

\section{Distribution and abundance of Congo Peafowl}

This survey confirmed the continued presence of Congo Peafowl within 13 of 20 of the $50 \mathrm{~km} \times 50 \mathrm{~km}$ survey blocks in the eastern Zaire where the occurrence of Congo Peafowl was first reported 30 to 60 years ago (Verheyen 1962). New locations for Congo Peafowl have been added, including a significant extension of the known range in the northeast, into the Ituri Forest. The easternmost report from the Ituri Forest is Epulu, where the bird is known by the local name of Nkowe, and a female was captured in a hunting net by pygmies in 1985 or 1986 .

Throughout its large range, the Congo Peafowl appears to have a patchy distribution consisting of local areas of occurrence separated by adjacent areas where the bird is not known to occur. Whether the Congo Peafowl is permanently absent from these areas is uncertain, since the species is elusive and easily escapes detection (Chapin 1937).

The Congo Peafowl does not appear to be abundant anywhere within its range. Our sighting rate of Congo Peafowl during the 1989-1992 Maiko Park 
survey was less than one bird per $250 \mathrm{~km}$ of transect (four sightings), with a total of eight encounters, visual and auditory, recorded in 15 months in the forest. In the 1995 survey of the Maiko Park, where the species was the object of search, two encounters in 2 weeks of fieldwork were recorded. Dupain et al. (in press) reported 12 sightings of Congo Peafowl over a 21-month period (1994-1996) in Equateur province in the north-western portion of the species range. Local hunters contacted by our survey were unanimous in reporting that encounters with Congo Peafowl were infrequent. Several hunters in the area north of the Maiko Park, where the species is widespread and locally common, reported that they would be lucky to catch as many as five Congo Peafowl in their lifetimes.

It is not clear why the Congo Peafowl should have such a sparse distribution. The species does not appear to have a specialized diet. Thompson (1996) reports Congo Peafowl attracted to a large, unidentified fruit in the Kasai. Other published records of fruits eaten by Congo Peafowl include widespread tree species common in forests throughout the region (Urban et al. 1986). Snow (1978) suggested that competition with Black Guineafowl Agelastes niger might limit the current distribution of Congo Peafowl. However, the ranges of these species are not mutually exclusive, as Snow suggested. We observed both Black Guineafowl and Plumed Guineafowl Guttera plumifera, as well as Latham's Francolin, in the same forest sites where Congo Peafowl were observed or reported captured. Lovel (1975) commented on the Congo Peafowl's susceptibility to diseases in captivity. Whether wild populations of Congo Peafowl are limited by disease outbreaks is not known.

Chapin (1937) speculated that the Congo Peafowl may have been originally more widespread and that the species' current restricted range reflects the impact of overhunting. While the Congo Peafowl is clearly vulnerable to heavy hunting pressure, this factor alone does not satisfactorily explain why it should not be common over large areas of the Ituri Bassin which includes some of the historically last and least settled forest in Central Africa (Vansina 1991). In contrast, Congo Peafowl occur, or have occurred recently, at a number of sites where human occupation has long been established.

Our survey results suggest that, although Congo Peafowl can be found in a variety of upland forest types, populations are often associated with areas of low hills or ridges between watersheds. The forested slopes in these areas often contain shallow soils supporting a dry type of forest with an open understorey. The type location for the Congo Peafowl was given as the upper Lukenie River (Chapin 1936). Although the exact location is not known, the area is primarily a drier forest type and not far from the savanna edge, a fact that did not escape Chapin (1937) who remarked that this location was unusual for a species dependent on rainforests. Cordier (1949) remarked on the association of Congo Peafowl with drier sites within forest in the Opala area, south of Kisangani. More recently, Thompson (1996) reported Congo Peafowl as locally common in the southern savanna ecotone in the Lukuru area, between the Sankuru and Lukenie rivers. These observations suggest that the Congo Peafowl's favoured habitat may be a relatively dry forest and that the apparently relict distribution of the species may reflect the limited availability of these dry forest types today. Although forest cover is thought to have been reduced by climatic aridity during the Quaternary 
(Hamilton 1992), floristic composition of forest areas was probably altered as well (Hart et al. 1996). It is possible that drier forest types, and the Congo Peafowl, were more common or widespread in the past.

\section{Conservation status}

Important populations of Congo Peafowl were recorded in the Lindi, Aruwimi, Tshopo and Maiko basins and in the northern sector of the Maiko National Park. Congo Peafowl appear to be uncommon in the Okapi Wildlife Reserve and the Kahuzi-Biega National Park, the only other protected areas in eastern Zaire where the species occurs. The Okapi Wildlife Reserve lies at the eastern limit of the Congo Peafowl's range. Elevations in the Kahuzi-Biega National Park frequently surpass $1200 \mathrm{~m}$, which appears to be the altitudinal limit of the species. Forest between the Lomami and Zaire rivers, south of Opala, may contain significant concentrations of Congo Peafowl, but our information from this area remains limited. Further fieldwork is needed in the western and southern parts of the Congo Peafowl's known range where recent reports (Dupain et al. in press, Thompson 1996) indicate that significant populations exist in areas where the species was previously unrecorded.

Congo Peafowl populations remain vulnerable throughout the survey region. Uncontrolled hunting is a major threat to the species. Subsistence hunting is a central feature of rural economies throughout eastern Zaire. Hunting for commercial markets is likely to increase as new areas are opened to logging and mining and as human populations move from the Rift Highlands into the lightly inhabited lowland forest frontiers to the west (Hart and Hall 1996). Congo Peafowl have declined, and in some cases have probably disappeared, in the Lubutu, Ubundu and Walikale areas and at a number of sites in the lower Aruwimi Valley, north of Kisangani. Based on survey results, Congo Peafowl are now either extirpated or only doubtfully present in seven of the twenty, $50 \mathrm{~km} \times 50 \mathrm{~km}$ quadrats within the survey region that were mapped by Verheyen (1962) as historically containing Congo Peafowl.

The conservation of Congo Peafowl will be best assured in protected areas where hunting can be limited or banned. With appropriate support, the Maiko National Park represents a significant potential for in situ conservation of Congo Peafowl. The occurrence of Congo Peafowl and the potential for in situ conservation of the species in the Salonga National Park should also be evaluated.

\section{Acknowledgements}

The Institut Zairois pour la Conservation de la Nature (IZCN) authorized our operations in the Maiko National Park and encouraged this survey.

Fieldwork for the survey was supported by the Wildlife Conservation Society. Additional financial contributions by BirdLife International, Richard Olsen, Rotterdam Zoo, Mr and Mrs Robert Williams, Michael Klat, Charles Sevelle, San Antonio Zoological Society and San Antonio Association of Animal Keepers are gratefully acknowledged. 


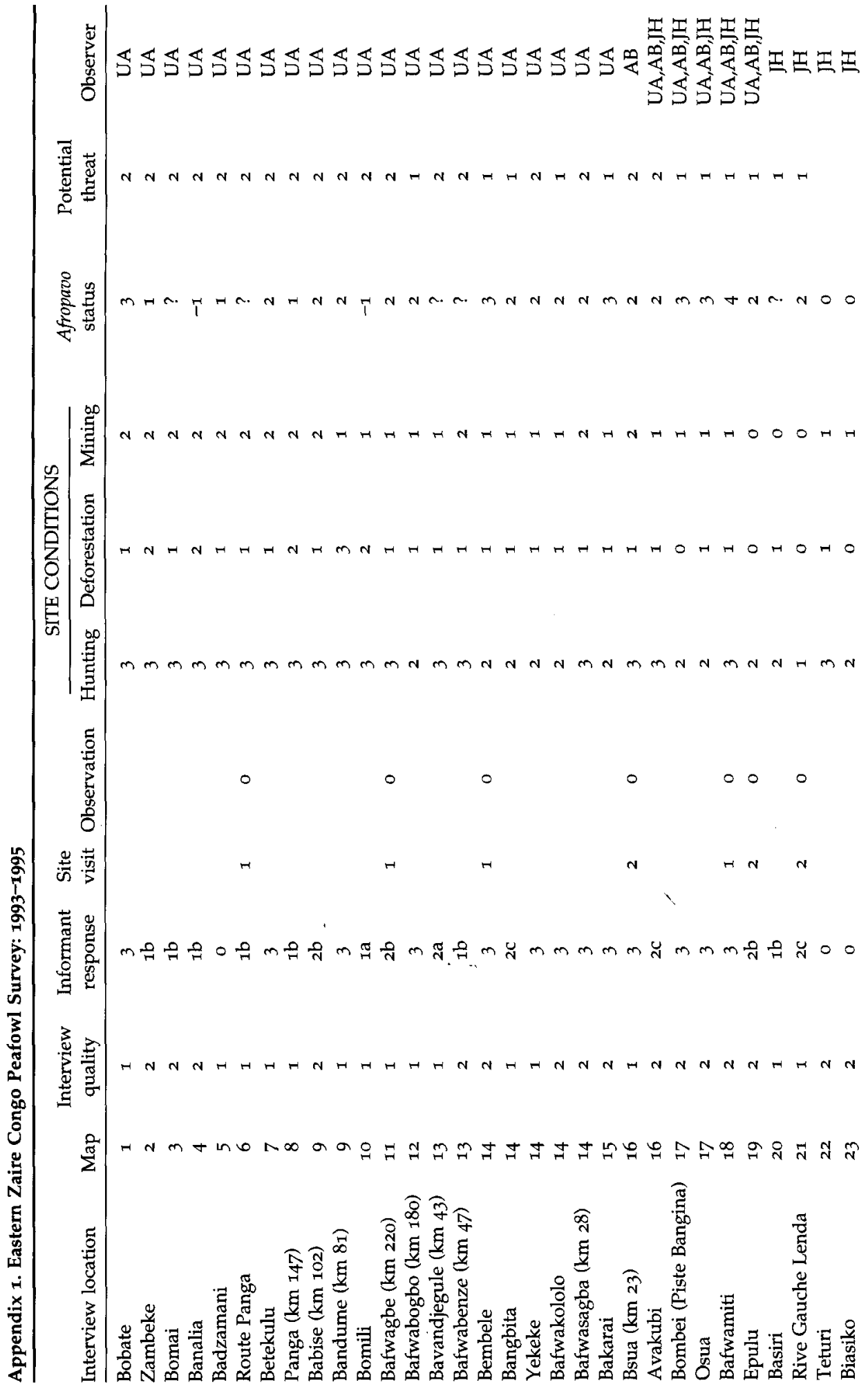




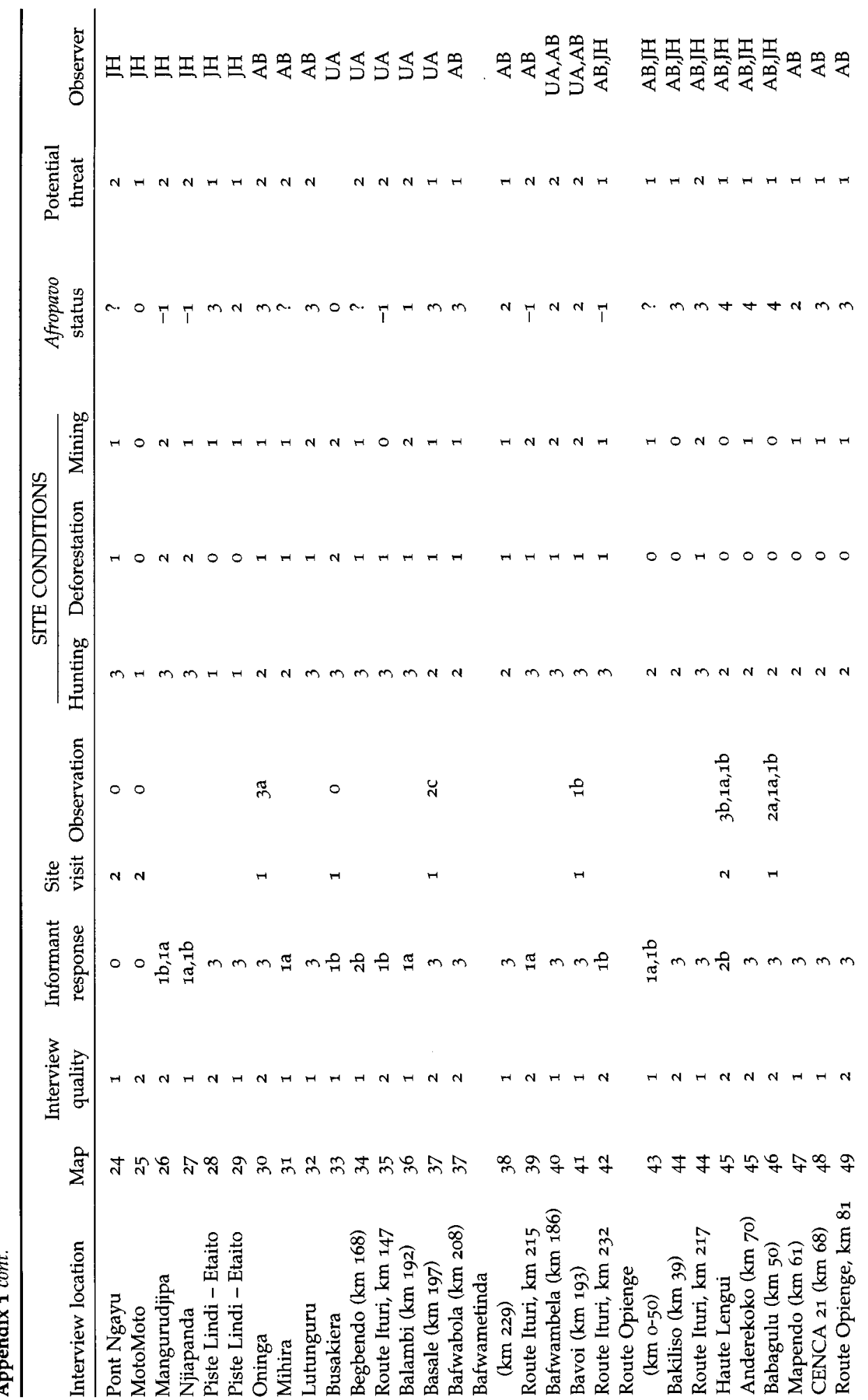




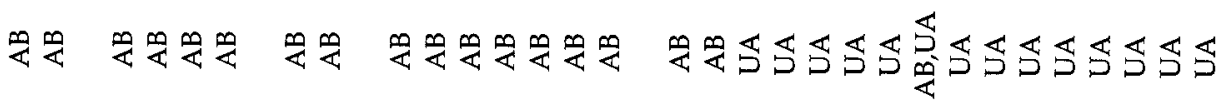

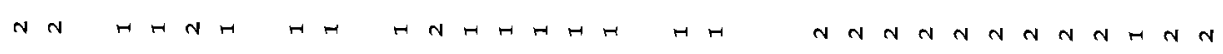

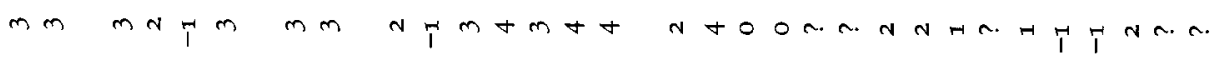

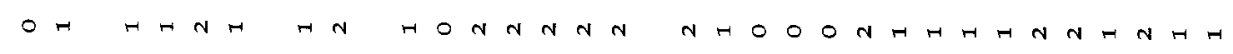

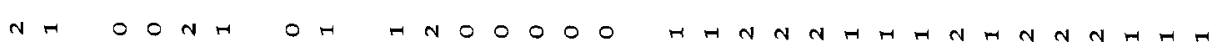

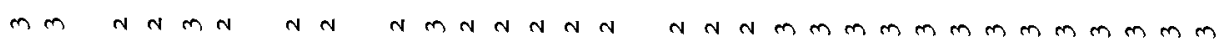
$\begin{array}{llll}0 & \text { ले ले } \\ N & H & H\end{array}$

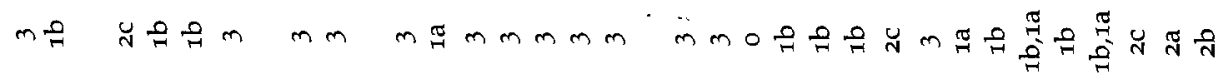

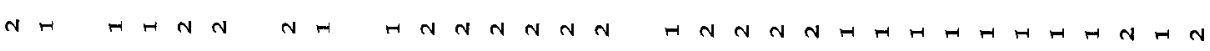

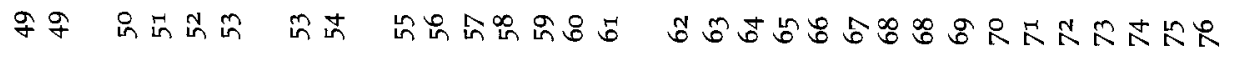

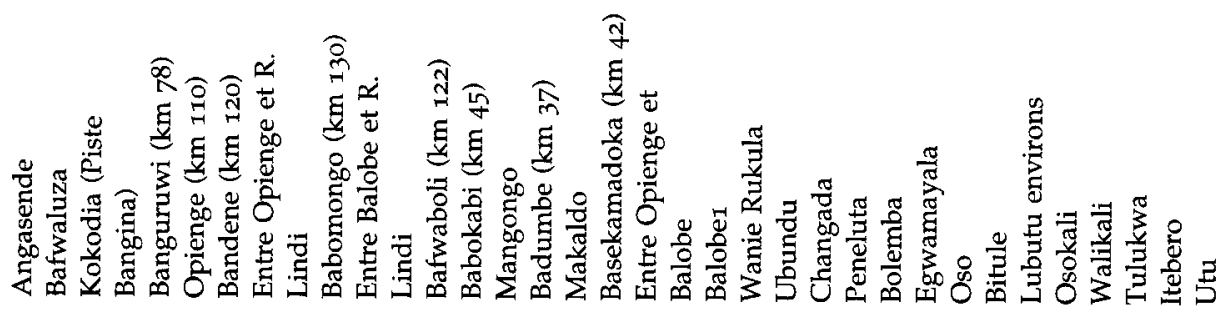


John A. Hart and Agenoga Upoki

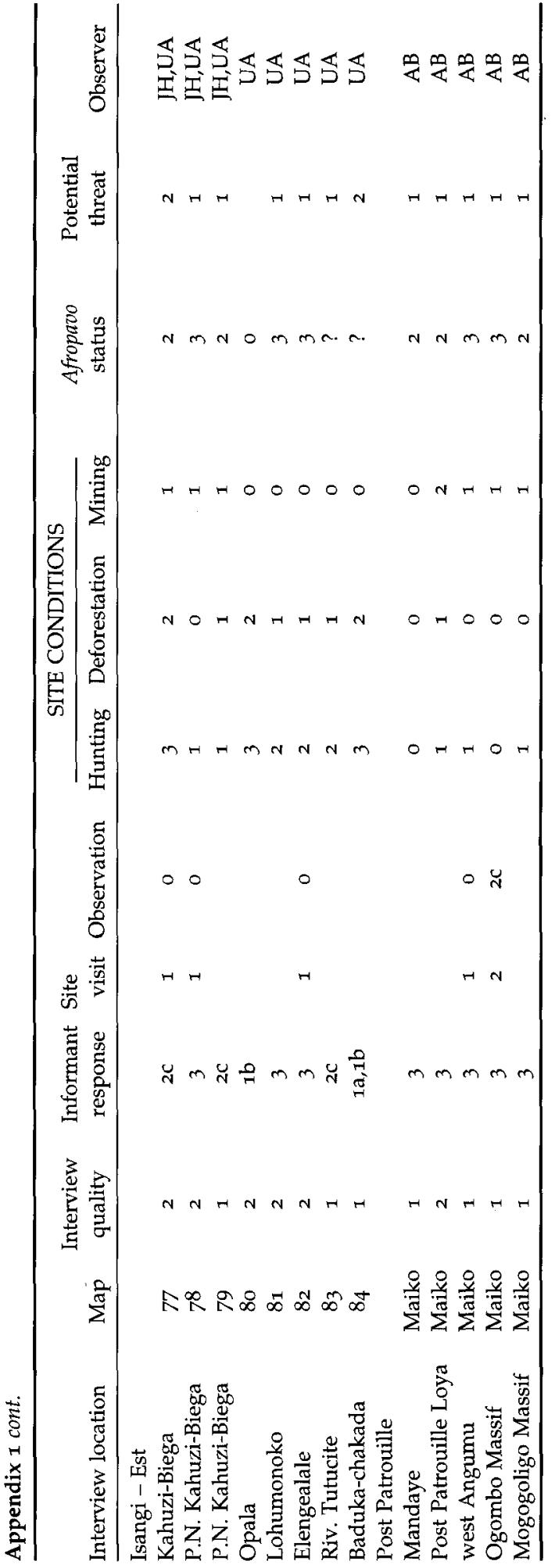




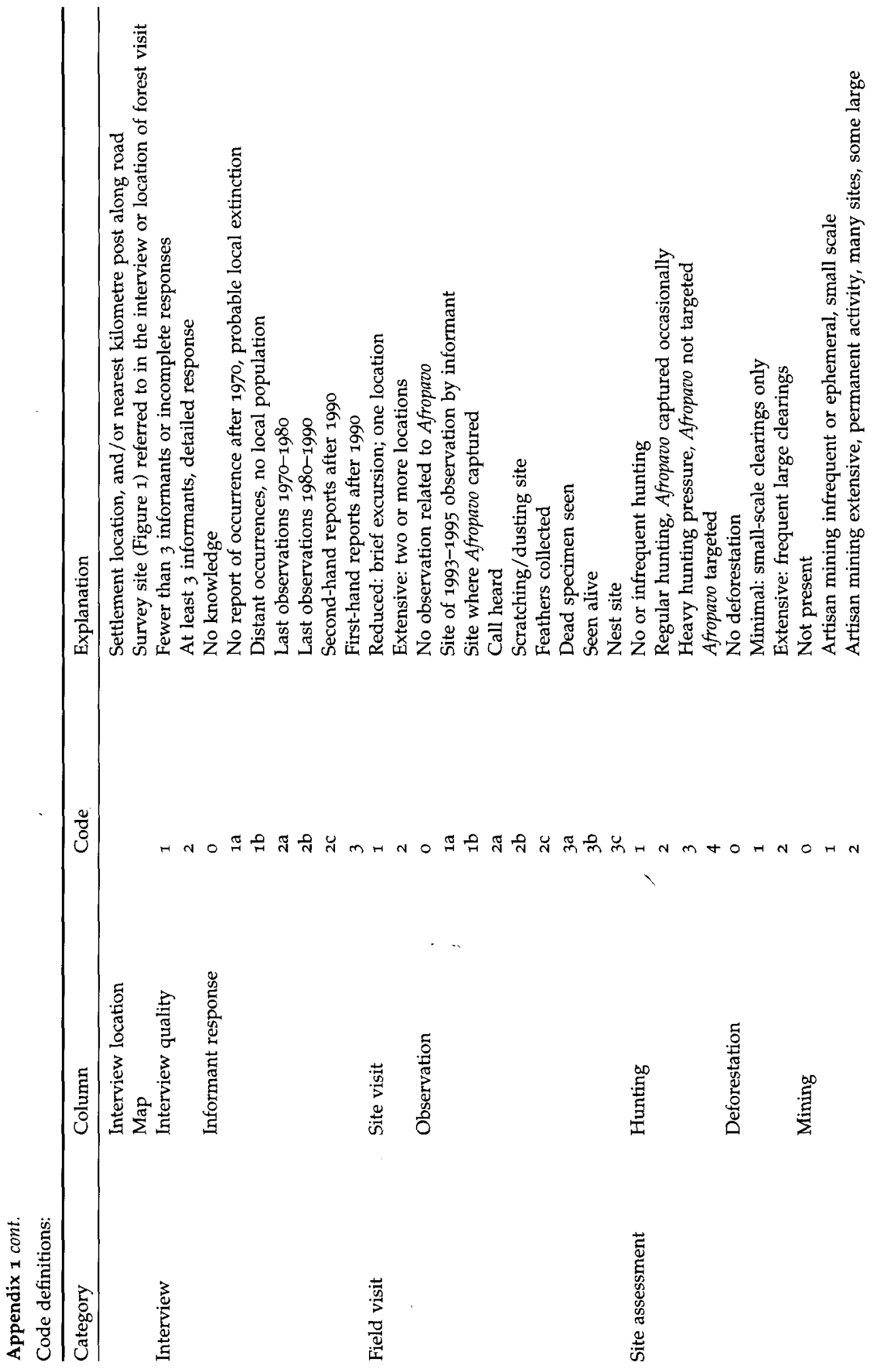




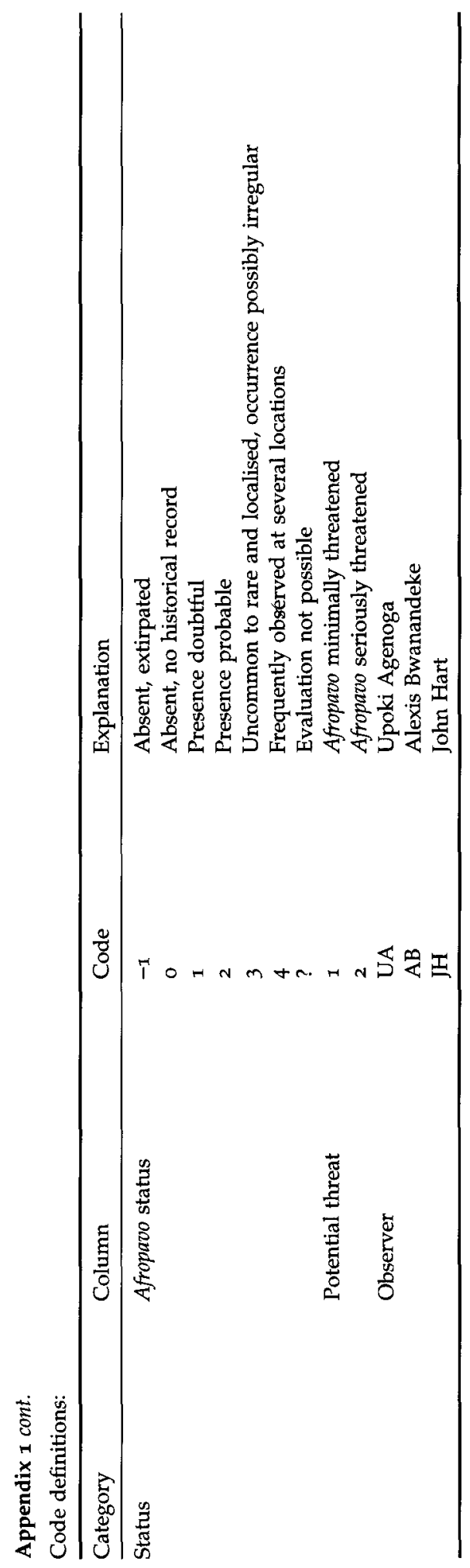


We should like to acknowledge the contributions in the field of A. Bwanandeke. C. Sikubwabo and J. Dupain generously provided details on observations of Congo Peafowl. R. Van Bocxstaele contributed bibliographical material. T. Hart, D. Bruning and C. Sheppard reviewed early drafts of this paper.

\section{References}

Chapin, J. (1932) Birds of the Belgian Congo, Part 1. Bull. Am. Mus. Nat. Hist. 65.

Chapin, J. (1936) A new peacock-like bird from the Belgian Congo. Rev. Zool. Bot. Afr. 29 (1): $1-6$.

Chapin, J. (1937) In pursuit of the Congo Peacock. Nat. Hist. 40: 725-732, 777-778.

Cordier, C. (1949) Further adventures of Charles Cordier. Animal Kingdom 52: 2-9, 28-29.

Dupain, J., Van Krunkelsven, E., and Van Elsacker, L. (in press) Recent observations of the Congo Peacock Afropavo congensis in the Equateur Province, Zaire. Ostrich.

Gérard, P. (1960) Etude écologique de la forêt dense à Gilbertiodendron dewevrei dans la région de l'Uele. Série scientifique No. 87. Publications de l'Institut National pour l'Etude Agronomique du Congo (I.N.E.A.C.)

Germain, R. and Evrard, C. (1956) Etude écologique et phytosociologique de la forêt à Brachystegia laurentii. Série scientifique No. 67. Institut National pour l'Etude Agronomique du Congo Belge (I.N.E.A.C.).

Hamilton, A. C. (1992) History of forests and climate. Pp. 17-25 in J. A. Sayer, C. S. Harcourt and N. M. Collins, eds. The conservation atlas of tropical forests, Africa. London: Macmillan.

Hart, J. and Hall, J. (1996) Status of eastern Zaire's forest parks and reserves. Conserv. Biol. 10: $316-327$.

Hart, J. and Sikubwabo, C. (1994) Exploration of the Maiko National Park of Zaire: 1989-1992. Bronx, New York: Wildlife Conservation Society (Working Paper No.2).

Hart, T. and Hart J. (1997) Conservation and civil conflict: two perspectives from central Africa. Conserv. Biol. 11: 1-8.

Hart, T., Hart, J., Dechamps, R., Fournier, M. and Ataholo, M. (1996) Changes in forest composition over the last 4,000 years in the Ituri basin, Zaire. Pp 545-563 in L. J. G. van der Maesen et al., eds. The biodiversity of African plants. Amsterdam: Kluwer.

Lovel, T. W. I (1975) The present status of the Congo peacock. J. World Pheasant Assoc. 1: 48-57.

Snow, D. W., ed. (1978) An atlas of speciation in African non-passerine birds. London: British Museum (Natural History).

Thompson, J. (1996) New information about the presence of the Congo Peafowl. World Pheasant Assoc. News. 50: 3-8.

Urban, E., Fry, C. and Keith, S. (1986) The birds of Africa, Vol. 1. London: Academic Press.

Van Bocxstaele, R. (1985) The Congo Peafowl (Afropavo congensis Chapin), including some new facts concerning the history of the bird in nature and the captive breeding program at Antwerp Zoo. Pp. 171-193 in C. Kruyfhooft, ed. Zoom op zoo: Antwerp zoo focusing on arts and sciences. Antwerp, Belgium: Royal Zoological Society of Antwerp.

Vansina, J. (1991) Paths in the rainforests: toward a history of political tradition in equatorial Africa. Madison: University of Wisconsin Press.

Verheyen, W. (1962). Quelques données concernant le dimorphisme sexuel, et la distribution géographique d'Afropavo congensis Chapin, ainsi qu'un essai de bibliographie générale. Pp 7-16 in W. Verheyen, ed. Monographie du paon congolais Afropavo congensis Chapin 1936. Bull. Soc. Roy. Zool. d'Anvers 26.

Verheyen, W. (1965) Der kongopfau (Afropavo congensis Chapin 1936). Stuttgart, Germany: Kosmos Verlag. 
Verschuren, J. (1978) Observations ornithologiques dans les parcs nationaux du Zaire, 1968-1974. Gerfaut 68: 3-24.

White, F. (1983) The vegetation of Africa: a descriptive memoir to accompany the UNESCO/AETFAT/UNSO vegetation map of Africa. Paris, France: UNESCO.

JOHN A. HART

Wildlife Conservation Society, 2300 Southern Blvd., Bronx, NY 10460 U.S.A.

AGENOGA UPOKI

Faculté des Sciences, Université de Kisangani, Kisangani, Zaire. 